\title{
Dry matter yield of rhizoma perennial peanut (Arachis glabrata) harvested at six, nine and 12 weeks at two semiarid sites ${ }^{1}$
}

\author{
Teodoro M. Ruiz', Rafael Ramos-Santana ${ }^{3}$ \\ and Antonio Sotomayor-Ríos ${ }^{4}$
}

J. Agric. Univ. P.R. 84(3-4):115-131 (2000)

\begin{abstract}
Rhizoma perennial peanut (RPP) is a forage legume of excellent adaptability and persistence inder subtropical and tropical conditions. Four accessions (USDA-TARS 17033, 17050, 17052, and 17097, with PI nos. 276233, 262826, 262833, and 262839, respectively) and two cultivars (Arbrook and Florigraze) of rhizoma perennial peanut (RPP) in Lajas, and two of the accessions (17033 and 17097) and cultivar Florigraze in Juana Díaz, Puerto Rico, were evaluated for dry matter yield (DMY) under irrigation during a full year. The RPPs were evaluated at six-, nine- and 12-wk harvest intervals $(\mathrm{HI})$ in each of the four seasons of the year. At both sites, yield of accession 17033 was highest $(P<0.01)$ and averaged $35,779 \mathrm{~kg} D M / h a / y r . ~ I n ~ L a j a s$, yield of accession 17097 was second best with an average of $30,151 \mathrm{~kg} \mathrm{DM} /$ $\mathrm{ha} / \mathrm{yr}$, yields of the other four RPPs were similar, averaging $25,374 \mathrm{~kg} \mathrm{DM} / \mathrm{ha} /$ yr. Cultivar Florigraze, which produced $16 \%$ less than accession 17097 in Lajas, had similar productivity in Juana Diaz. On average, the total yields of accessions 17033 and 17097 and cultivar Florigraze declined $(P<0.01)$ by about 35 and $27 \%$ at the two locations, respectively, as $\mathrm{HI}$ increased from six to 12 weeks. Season of harvest had a strong influence on the DMY of RPP. At both locations, 69 and $64 \%$ of total yields were produced during spring and summer, respectively. Differences in height among RPPs were significant $(P<0.01)$ at both locations. Height averaged $26.0,17.6$, and $18.5 \mathrm{~cm}$ for accessions 17033 and 17097 and cultivar Florigraze, respectively. The great adaptability of RPP to the tropical environment, and its high yield when harvested for hay, make it a crop with the potential of becoming one of the most important forages in the tropics.
\end{abstract}

Key words: Tropical legume, hay, Florigraze, rhizoma peanut

RESUMEN

Rendimiento de maní rizoma perenne (Arachis glabrata) cosechado a seis, nueve y 12 semanas en dos localidades semiáridas

Cuatro accesiones (USDA-TARS líneas núm. 17033, 17050, 17052 y 17097; núm. PI $276233,262826,262833$ y 262839, respectivamente) y dos

'Manuscript submitted to Editorial Board 6 July 2000.

${ }^{2}$ Assistant Researcher, Department of Animal Science, University of Puerto RicoMayagüez, P.O. Box 9030, Mayagüez, PR 00680-9030.

"Associate Researcher, Department of Agronomy and Soils.

${ }^{1}$ Research Agronomist, Retired, USDA-ARS, Tropical Agriculture Research Station, Mayagüez, now Agronomist, Department of Agronomy and Soils. 
cultivares (Arbrook y Florigraze) de maní rizoma perenne (MRP) en Lajas, y dos accesiones (17033 y 17097) y Florigraze en Juana Díaz, Puerto Rico, se evaluaron para rendimiento de materia seca durante un año, en años consecutivos. Los MRP fueron evaluados a intervalos entre cosechas de seis, nueve y 12 semanas en cada una de las estaciones del año. En ambas localidades el rendimiento de materia seca (MS) de la accesion 17033 fue mayor ( $\mathrm{P}<0.01$ ), promediando $35,779 \mathrm{~kg}$ MS/ha/año. En Lajas, el rendimiento de la 17097 fue el segundo mayor con $30,151 \mathrm{~kg}$ MS/ha/año y el de los otros cuatro MRP fue similar y menor que el rendimiento de 17097, promediando $25,374 \mathrm{~kg}$ MS/ha/año. Florigraze produjo $16 \%$ menos MS que la 17097 en Lajas; sin embargo, en Juana Diaz la producción de las dos fue similar. A medida que el intervalo de cosecha se aumentó de seis a 12 semanas el rendimiento promedio de la 17033, 17097 y Florigraze se redujo $(\mathrm{P}<0.01)$ en alrededor de 35 y $27 \%$ en Lajas y Juana Diaz, respectivamente. En ambas localidades el 69 y el $64 \%$ del redimiento total de MS se produjo en la primavera y el verano, respectivamente. Las diferencias en la altura de la planta entre los MRP fueron significativas $(P<0.01)$ en ambas localidades. La altura promedio de las plantas fue $26.0,17.6$ y $18.5 \mathrm{~cm}$ para las accesiones 17033 y 17097, y Florigraze, respectivamente. La gran adaptabilidad del MRP al medio ambiente tropical y su alto rendimiento, cuando es cosechado para heno, hacen del mismo un cultivo con el potencial de ser uno de los forrajes de mayor importancia en el trópico.

\section{INTRODUCTION}

Harvesting rhizoma perennial peanut (RPP) for hay production is a well established agricultural enterprise in the southeastern United States (French and Prine, 1991), with thousands of hectares dedicated to its cultivation. Unlike most other legumes, RPP has demonstrated adaptability and excellent persistence under tropical and subtropical conditions. Once established, RPP has demonstrated that it can compete aggressively with grasses and has persisted for over 20 years under subtropical conditions (French and Prine, 1989). It also has low maintenance requirements when harvested regularly for hay. No significant damage due to insects or disease has been reported under commercial or experimental conditions.

Fertilization is not recommended during establishment or production (Prine et al., 1981). The lack of response of RPP to nitrogen fertilization was observed under field conditions despite some positive response under greenhouse conditions (Venuto et al., 1998). Thus, effectively nodulated RPP can fix sufficient $N$ to meet the requirements for maximum herbage production for the species. Furthermore, RPP has been found to be tolerant of a wide range of soil $\mathrm{pH}$ from an alkaline 7.8 to an acid 4.0. It grew well in an Oxisol (Valencia, 1993) with a pH of about 6.5 and also in sandy soil (Prine et al., 1981) with a $\mathrm{pH}$ between 4.0 and 5.0. Amending an acid soil to raise its $\mathrm{pH}$ to 6.0 has not been justified in terms of adaptability or yield of DM (Prine et al., 1981).

In subtropical environments, seasonal yields of hay from established RPP fields can be expected to range between 6,800 and $13,600 \mathrm{~kg} / \mathrm{ha}$ on 
nonirrigated land (French and Prine, 1989). These yields are based on three to four cuttings per season at a six- to 10-wk harvest interval, depending on climatic conditions. In Louisiana, Venuto et al. (1998) reported a maximum DMY for the commercial variety Florigraze of $10,800 \mathrm{~kg} / \mathrm{ha}$ over a four-month growing period. In Puerto Rico, Valencia et al. (1997) evaluated dry matter yields of 10 of the most promising introduced accessions, as well as cultivars Florigraze and Arbrook, over a growing period extending from June to November. Average yields obtained were similar to those reported in Florida for a similar growing period (French and Prine, 1989; Prine et al., 1981). In spite of this, there were large differences in yield observed among the accessions evaluated. Therefore, the objective of these studies were to study superior cultivars among those evaluated by Valencia (1993) and to determine their yield potential relative to two commercial cultivars.

\section{MATERLALS AND METHODS}

Six RPPs were evaluated at the Lajas Substation (Lajas) and three at the Juana Diaz Substation (Juana Díaz) of the Agricultural Experiment Station of the University of Puerto Rico, for DMY during one year in consecutive years. Irrigation to supply at least $2.5 \mathrm{~cm}$ of water per week, as needed, was provided at both sites throughout the evaluation period. In Lajas drip irrigation was used; in Juana Díaz, aerial irrigation. At both sites RPPs were planted in a San Antón soil (fine-loamy, mixed, isohyperthermic Cumulic Haplustolls). At Juana Díaz, soil at the experimental site had a $\mathrm{pH}$ of 7.68; $\mathrm{pH}$ at the Lajas site was approximately 7.5.

Lajas Experiment: Accessions USDA-TARS 17033, 17050, 17052, and 17097 (PI no. 276233, 262826, 262833, and 262839, respectively) and commercial cultivar's Florigraze and Arbrook were evaluated for DMY at harvest intervals of six, nine, and 12 weeks. The experimental design used was a split-plot in space and time of a randomized complete block with four replications. Peanut cultivars and accessions were assigned to $22.6 \mathrm{~m}^{2}(3.7 \times 6.1 \mathrm{~m})$ whole plots. Plots were divided in half, lengthwise, and each half was divided into three equal parts which were randomly assigned to one of the three harvest intervals. Thus, sampling was taken once in each of the two sections within the plot for each of the three harvest intervals studied during each of the four seasons studied. Each plot received the equivalent of $568 \mathrm{~kg} / \mathrm{ha} / \mathrm{yr}$ of a fertilizer with the formula $0(\mathrm{~N})-10(\mathrm{P})-20(\mathrm{~K})-10(\mathrm{~S})-10(\mathrm{Mg})$ in three applications, once every four months. The use of herbicides or insecticides was not necessary during the period evaluated.

The trial began after a standardization cut which was given to all plots early in January 1996. After that time, there were eight total har- 
vests made for the 6-wk, five for the 9-wk, and four for the 12-wk harvest intervals during the year of evaluation. Within each harvest interval, harvest dates were assigned to seasons according to when most of the growth of the stand occurred for that particular harvest date. Winter included harvests for a period when most of the growth occurred from January to March; similarly, spring from April to June, summer from July to September; and fall from October to December.

Plant height was measured with a graduated steel meter for each of the three harvest intervals during the months of January to June 1996. Two measurements were made at each of the sampling sites (four per plot) for each harvest interval. These four readings were averaged, and a single value per plot per harvest was reported.

Forage was cut from a $0.45-\mathrm{m}$ square in each of the two plot sections to a residual height of about $4 \mathrm{~cm}$. Two forage samples per plot were collected in cloth bags and dried in an air-draft oven at $60^{\circ} \mathrm{C}$ for $48 \mathrm{~h}$. Samples were then weighed to determine DMY. Reported values were the average yields of the two samples taken within each plot for each harvest interval and season.

Experimental data were analyzed by least squares ANOVA using the General Linear Model procedure of SAS (Littell et al., 1991). The mathematical model used to analyze the data was

$$
\frac{Y_{i j k m !}=}{\mu+\alpha_{i}+\beta_{j}+\gamma_{k}+\rho_{1}+(\alpha \beta)_{i j}+(\alpha \beta \rho)_{i j l}+(\alpha \gamma)_{i k}+(\alpha \gamma \rho)_{i 1}+(\beta \gamma)_{j k}+(\alpha \beta \gamma)_{i j k}+\varepsilon_{i j k l}}
$$

Where:

$$
\begin{aligned}
& \mu=\text { overall mean } \\
& \alpha_{i}=\text { effect of peanut accession or cultivar } \mathrm{i} \\
& \beta_{\mathrm{j}}=\text { effect of harvest interval } \mathrm{j} \\
& \gamma_{\mathrm{k}}=\text { effect of season } \mathrm{k} \\
& \rho_{\mathrm{I}}=\text { effect of block } 1 \\
& \varepsilon_{\mathrm{ijkl}}=\text { residual effect of } \mathrm{i}, \mathrm{j}, \mathrm{k} \text { and } \mathrm{l} \\
& \mathrm{Y}_{\mathrm{ijkm}}=\text { response variable for peanut } \mathrm{i} \text { for harvest interval } \mathrm{j} \text { in } \\
& \quad \text { season } \mathrm{k} \text { for in block } \mathrm{l} \text {. }
\end{aligned}
$$

A total of 288 measurements were used for each response variable. Ftests were used to determine the significance of main effects and interactions. Pre-planned comparisons of means were made by using the LSD and orthogonal contrasts.

Juana Díaz Experiment: Accessions 17033 and 17097 and cultivar Florigraze were evaluated for DMY at six-, nine-, and 12-wk harvest intervals. These two accessions were selected for this trial because they had shown greater yield potential than the other two accessions stud- 
ied in Lajas. Florigraze, the most widely planted commercial variety, was used as a control for comparison purposes. The experimental layout was as in the Lajas experiment with the use of $6 \times 5 \mathrm{~m}$ plots. No fertilizer, herbicide or insecticide was applied during the experiment. Plots were divided lengthwise into three equal segments. A harvest interval was randomly assigned to each segment within the plot, and the segments were harvested during each of the four seasons of the year. A standarization cut, to begin the trial, was given to all plots in the second week of October 1996.

Plant height was measured with a graduated steel meter at six locations within each segment of the plot assigned to a particular date and harvest interval. Unlike the method used in the Lajas experiment, at this site the plant height was measured prior to all forage samplings during the four seasons of the year. Forage samples were obtained from a $0.91 \mathrm{~m}$ square randomly placed within each segment and harvested to a residual height of $4 \mathrm{~cm}$. A set number of samples for each harvest interval were obtained and handled as in the Lajas experiment. Seasonal assignment of harvest dates within each harvest interval was done according to the procedure used in the Lajas experiment. Data for DMY and height of the plant were analyzed by using SAS as in the Lajas experiment.

\section{RESULTS}

\section{Lajas Experiment}

\section{Dry Matter Yield}

Accession 17033 produced the highest $(\mathrm{P}<0.01) \mathrm{DMY}$ among the RPPs studied (Table 1 ). It produced $21.9 \%$ more DM than accession 17097 , the second highest producer, and $44.8 \%$ more than the average of the other four RPPs. Harvest interval had a negative effect on DMY $(\mathrm{P}<0.01)$. As harvest interval increased from six to 12 weeks, total yield decreased by $12,994 \mathrm{~kg} / \mathrm{ha} / \mathrm{yr}$, a $37.5 \%$ reduction. The effect of harvest interval on total DMY was similar for all lines of RPP studied.

Yield of DM per harvest ( $\mathrm{kg} / \mathrm{ha}$ ) of the four accessions and two cultivars (Table 2) followed a pattern similar to that of total yield $(\mathrm{kg} / \mathrm{ha} /$ yr). Yield per harvest of accession 17033, averaged over harvest intervals, was $22.9 \%$ higher $(\mathrm{P}<0.01)$ than that of 17097 and $45 \%$ higher than the average of the other four RPPs. Average yield per harvest as affected by harvest interval showed a quadratic increase $(P<0.01)$ with an increasing length of time. Yield per harvest increased by $21.4 \%$ from six to nine weeks. However, yield per harvest remained constant from nine to 12 weeks. Accession 17033 consistently out yielded the 
TABLE 1.-Total dry matter (DM) yield of four accessions (USDA-TARS 17033, 17050, 17052 and 17097) and two cultivars (Arbrook and Florigraze) of rhizoma perennial peanut (RPP) harvested at six-, nine- and 12- wk harvest intervals during a full year in Lajas.

\begin{tabular}{lcccc}
\hline & \multicolumn{3}{c}{ Harvest interval (HI) } \\
\cline { 2 - 3 } RPP & 6 -wk & 9 -wk & 12 -wk & \multirow{2}{*}{ Mean $^{1}$} \\
\hline & & & & \\
17033 & 43,912 & 38,254 & 28,102 & $36,755^{\circ}$ \\
17050 & 31,787 & 27,216 & 19,515 & $26,173^{\circ}$ \\
17052 & 30,910 & 22,215 & 19,546 & $24,224^{c}$ \\
17097 & 37,692 & 30,237 & 22,525 & $30,151^{\circ}$ \\
Florigraze & 29,345 & 25,585 & 20,990 & $25,307^{\circ}$ \\
Arbrook & 34,179 & 24,595 & 19,183 & $25,986^{\circ}$ \\
Mean $^{2}$ & 34,637 & 28,017 & 21,643 & RPP $\times \mathrm{HI}^{3}$ \\
\hline
\end{tabular}

'Differences among means with different letters are statistically significant at $\mathrm{P}<$ 0.01 .

${ }^{2}$ Linear decrease with an increase in the harvest interval, $\mathrm{P}<0.01$.

${ }^{3}$ Interaction between RPP line and HI was not significant at $\mathrm{P}<0.05$.

other RPPs at the six-, nine-, and 12-wk harvest intervals. Only accession 17052, with the lowest DMY at the nine-wk harvest, showed a tendency to increase its yield at the 12-wk harvest.

Season had a marked effect $(\mathrm{P}<0.01)$ on DMY of RPP. Seasonal yield averaged for harvest interval was $3,100,5,707,6,954$, and 2,638 $\mathrm{kg} / \mathrm{ha}$ for the winter, spring, summer, and fall seasons, respectively. Yield per harvest was highest during summer $(\mathrm{P}<0.01)$; the average yield during summer and spring was greater than that of fall and winter (Figure 1). During winter, accession 17033 produced only $3,824 \mathrm{~kg} /$ ha per harvest; this production was similar to that of accession 17097. However, in spring, yield of accession 17033 was $91.4 \%$ greater $(\mathrm{P}<$ $0.05)$ than in winter and $24.6 \%$ higher $(\mathrm{P}<0.05)$ than for accession 17097 in the same season. Further increases in yield $(\mathrm{P}<0.05)$ for accession 17033 occurred during summer, production was $10,038 \mathrm{~kg} / \mathrm{ha}$ or about 2.62 times that of winter and $42.7 \%$ higher than that of the second best RPP (17097) for the same period. Yield among cultivars 17033, 17050 and 17097 was similar $(\mathrm{P}<0.05)$ and higher than yields of the other three during fall.

The effect of harvest interval on DMY was modified by season (interaction season $\times$ harvest interval, $\mathrm{P}<0.01$ ) of the year (Table 3 ). During winter there were no yield differences between the nine- and 12 -wk harvests intervals. During summer, when the highest yields 
TABLE 2-Dry matter (DM) yield per harvest of four accessions (USDA-TARS 17033, 17050, 17052 and 17097) and two cultivars (Arbrook and Florigraze) of rhizoma perennial peanut (RPP) harvested at six-, nine-and 12-wh harvest intervals during a full year in Lajas.

\begin{tabular}{|c|c|c|c|c|}
\hline \multirow[b]{2}{*}{ RPP } & \multicolumn{3}{|c|}{ Harvest interval (HI) } & \multirow[b]{2}{*}{ Mean' } \\
\hline & 6 -wk & 9 -wk & $12-w k$ & \\
\hline \multicolumn{5}{|c|}{$\ldots \ldots \ldots$} \\
\hline 17033 & 5,053 & 6,607 & 6,475 & $6,045^{:}$ \\
\hline 17050 & 3,658 & 4,704 & 4,497 & $4,286^{\mathrm{c}}$ \\
\hline 17052 & 3,557 & 3,837 & 4,502 & $3,965^{\mathrm{c}}$ \\
\hline 17097 & 4,337 & 5,222 & 5,190 & $4,916^{b}$ \\
\hline Florigraze & 3,374 & 4,419 & 4,834 & $4,209^{c}$ \\
\hline Arbrook & 3,933 & 4,248 & 4,399 & $4,193^{\mathrm{c}}$ \\
\hline Mean ${ }^{2}$ & 3,985 & 4,839 & 4,983 & $\mathrm{RPP} \times \mathrm{HI}^{3}$ \\
\hline
\end{tabular}

'Differences among means with different letters are statistically significant at $\mathrm{P}<$ 0.01 .

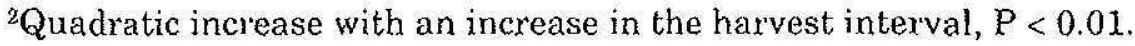

IInteraction between RPP line and HI was not significant at $\mathrm{P}<0.05$.

were recorded, yield increased $(\mathrm{P}<0.01)$ from the six- to the nine-, and from the nine- to the 12 -wk harvests by 36.2 and $6.7 \%$, respectively. During fall, there were significant $(\mathrm{P}<0.05)$ yield differences between the six- and nine-, and nine- and 12-wk harvests. In summer, yield per harvest for the nine- and 12 -wk harvest intervals was greatest $(\mathrm{P}<$ $0.01)$. However, for the six-wk harvest, yield during spring and summer was similar. For the six- and nine-wk harvests yield was greater $(\mathrm{P}<$ 0.05 ) during winter than fall. However, for the 12-wk harvest yield was similar during fall and winter.

\section{Plant Height}

Accession 17033 was the tallest $(\mathrm{P}<0.05)$ of the six RPPs studied (Table 4). Average height of 17033 over the three harvest intervals was 48\% taller than for accessions 17050 and 17097 and cultivars Florigraze and Arbrook. Accession 17052 had the shortest plants of all the RPPs studied at this site.

Increasing the harvest interval from six to 12 weeks resulted in a quadratic increase $(\mathrm{P}<0.01)$ in the mean height of the plant from 16.5 to $22.9 \mathrm{~cm}$ (Table 4). After increasing in height $33.9 \%$ from six to nine weeks, plants did not grow taller from nine to 12 weeks. The tallest (P $<0.05$ ) plants at each of the three harvest intervals studied were clearly those of accession 17033. This RPP increased $(\mathrm{P}<0.05)$ in height from 


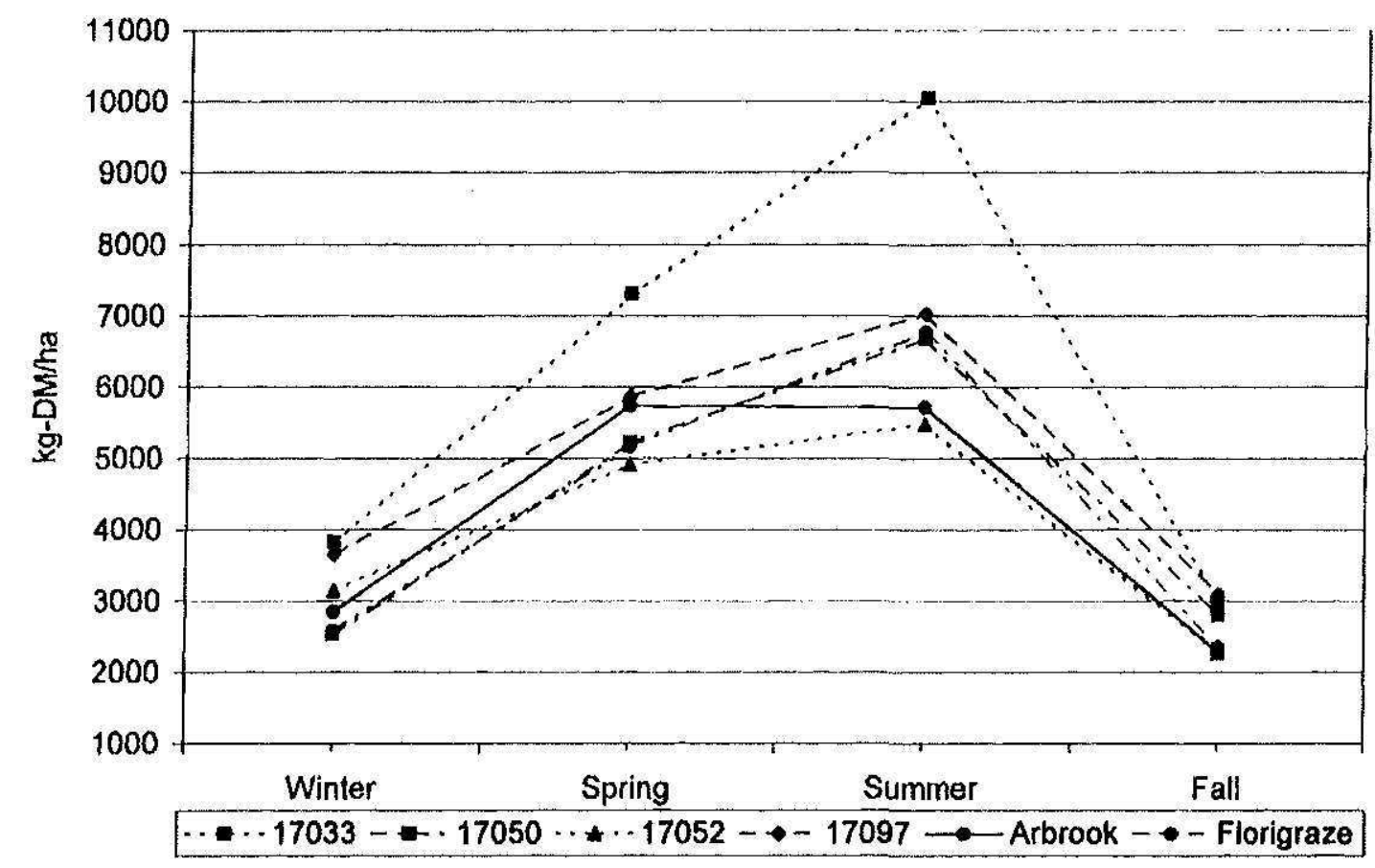

FIGURE 1. Means for dry matter yield of accessions (USDA.TARS 17033, 17050, 17052 and 17097) and two cultivars (Arbrook and Florigraze) of rhizoma perennial peanut averaged for the six-, nine- and 12 -wk harvests during the four seasons of the year in Lajas.

the six- to the nine-wk harvests, and was the only one that showed a tendency to increase from the nine- to the 12 -wk harvest intervals.

\section{Juana Díaz Experiment}

\section{Dry Matter Yield}

Among the three RPP lines evaluated, DM yield (kg/ha/yr) was different $(\mathrm{P}<0.01)$ when averaged across harvest intervals (Table 5). Yield of accession 17097 and cultivar Florigraze were not different. However, accession 17033 averaged $11.4 \%$ more $(\mathrm{P}<0.01) \mathrm{DM}$ production than the average of the other two RPPs. The RPP lines produced different $(\mathrm{P}<0.01)$ average total yield $(\mathrm{kg} \mathrm{DM} / \mathrm{ha} / \mathrm{yr})$ when harvested at six-, nine-, and 12-wk intervals. Increasing harvest interval had a negative effect on total yield $(\mathrm{P}<0.01)$. An increase in length of harvest interval from six to 12 weeks resulted in a $27.2 \%$ reduction in yield. This effect on estimated total production ( $\mathrm{kg} \mathrm{DM} / \mathrm{ha} / \mathrm{yr})$ was similar for the three RPPs studied.

Yield per harvest ( $\mathrm{kg} \mathrm{DM} / \mathrm{ha}$ ) of the two accessions and Florigraze at different harvest intervals followed a pattern similar to that for total yield (Table 6). Average yield per harvest of accession 17033 was about $12.9 \%$ higher $(\mathrm{P}<0.01)$ than the average of the other two RPPs. Yield 
TABLE 3.-Dry matter (DM) yield per harvest of four accessions (USDA-TARS 17033, 17050, 17052 and 17097) and lwo cultivars (Arbrook and Florigraze) of rhizoma perennial peanut (RPP) for each harvest interval during the four seasons of the year in Lajas.

\begin{tabular}{lccc}
\hline & \multicolumn{3}{c}{ Harvest interval (HI) ${ }^{1.2}$} \\
\cline { 2 - 4 } Season & 6 -wk & 9 -wk & 12 -wk \\
\hline \multirow{3}{*}{ Winter } & $2,795^{\mathrm{b}}$ & $3,243^{\mathrm{a}}$ & $3,263^{\mathrm{a}}$ \\
Spring & $5,582^{\mathrm{b}}$ & $6,077^{\mathrm{a}}$ & $5,461^{\mathrm{b}}$ \\
Summer & $5,468^{\mathrm{b}}$ & $7,447^{\mathrm{a}}$ & $7,947^{\mathrm{a}}$ \\
Fall & $2,097^{\mathrm{b}}$ & $2,591^{\mathrm{b}}$ & $3,260^{\mathrm{a}}$ \\
\hline
\end{tabular}

'Differences among means with different letters in the same row are statistically significant at $\mathrm{P}<0.05$.

Interaction between season and HI was significant at $\mathrm{P}<0.01$.

increased $(\mathrm{P}<0.01)$ as harvest interval increased from six to 12 weeks. Average yield increases of $45.9 \%$ were observed when the harvest interval increased from six to 12 weeks. Harvesting at a nine-wk harvest interval resulted in only $14.7 \%$ increase $(\mathrm{P}<0.01)$ in average yield per harvest over that at six weeks. A further increase of $27.2 \%$ in average DMY was observed at the 12-wk compared to the nine-wk harvest.

TARLE 4.-Plant height of four accessions (USDA-TARS 17033, 17050, 17052 and 17097) and two cultivars (Arbrook and Florigraze) of rhizoma perennial peanul (RPP) harvested at six-, nine- and 12- wh harvest intervals in Lajas.

\begin{tabular}{|c|c|c|c|c|}
\hline \multirow[b]{2}{*}{ RPP } & \multicolumn{3}{|c|}{ Harvest interval (HI) } & \multirow[b]{2}{*}{ Mean $^{i}$} \\
\hline & $6-w k$ & 9 -wk & 12-wk & \\
\hline \multicolumn{5}{|c|}{$\ldots$} \\
\hline 17033 & 22.7 & 29.9 & 35.2 & $29.3^{a}$ \\
\hline 17050 & 15.1 & 24.0 & 22.4 & $20.5^{c}$ \\
\hline 17052 & 13.8 & 15.6 & 13.9 & $14.5^{\mathrm{c}}$ \\
\hline 17097 & 15.5 & 19.3 & 20.6 & $18.6^{\mathrm{b}}$ \\
\hline Florigraze & 15.7 & 20.9 & 23.6 & $20.0^{c}$ \\
\hline Arbrook & 15.9 & 22.9 & 21.3 & $20.0^{c}$ \\
\hline Mean $^{2}$ & 16.5 & 22.1 & 22.9 & $\mathrm{RPP} \times \mathrm{HI}^{3}$ \\
\hline
\end{tabular}

'Differences among means with different letters are statistically significant at $\mathrm{P}<$ 0.05 .

${ }^{2} Q$ Quadratic increase with an increase in the harvest interval, $\mathrm{P}<0.01$.

'Interaction between RPP line and $\mathrm{HI}$ was not significant, $\mathrm{P}=0.132$. 
TABLE 5.-Total dry matter (DM) yield of accessions (USDA-TARS 17033, 17097) and a cultivar (Florigraze) of rhizoma perennial peanut (RPP) harvested at six., nine- and 12-wh harvest intervals during a full year in Juana Diaz.

\begin{tabular}{|c|c|c|c|c|}
\hline \multirow[b]{2}{*}{ RPP } & \multicolumn{3}{|c|}{ Harvest interval (HI) } & \multirow[b]{2}{*}{ Mean' } \\
\hline & 6 -wk & 9 -wk & 12-wk & \\
\hline \multicolumn{5}{|c|}{$\ldots \ldots \ldots$ kg-DM/ha/year $\ldots \ldots \ldots \ldots$} \\
\hline 17033 & 40,308 & 32,417 & 31,685 & $34,804^{\mathrm{n}}$ \\
\hline 17097 & 39,446 & 28,775 & 26,002 & $31,408^{b}$ \\
\hline Florigraze & 37,415 & 28,337 & 27,531 & $31,094^{b}$ \\
\hline Mean'2 & 39,056 & 29,843 & 28,406 & $\mathrm{RPP} \times \mathrm{HI}^{3}$ \\
\hline
\end{tabular}

Differences among means with different letters are statistically significant at $\mathrm{P}<$ 0.01 .

${ }^{2} \mathrm{Q}$ uadratic decrease with an increase in the harvest interval, $\mathrm{P}<0.01$.

${ }^{3}$ Interaction between RPP line and HI was not significant at $\mathrm{P}<0.05$.

Season of the year affected $(\mathrm{P}<0.01)$ growth and subsequent $\mathrm{DMY}$ of RPPs (Figure 2). When averaged for harvest interval and type of RPP, yields per harvest were higher $(\mathrm{P}<0.01)$ during spring and summer $(6,914$ and $6,778 \mathrm{~kg} \mathrm{DM} / \mathrm{ha}$, respectively) compared to that of winter and fall $(3,263$ and 4,589 , respectively). The average yield during spring and summer was 1.75 times greater than during fall and winter (Figure 2). Yield was similar during spring and summer, and greater $(\mathrm{P}<0.01)$ in fall than in winter. However, growth during fall de-

TABLE 6.-Average dry matter (DM) yield per harvest of two accessions (USDA-TARS 17033, and 17097) and a cultivar (Florigraze) of rhizoma perennial peanut (RPP) harvested at six-, nine-, and 12 wh harvest intervals during a full year in Juana Diaz.

\begin{tabular}{lcccc}
\hline & \multicolumn{3}{c}{ Harvest interval (HI) } & \\
\cline { 2 - 4 } RPP & 6 -wk & $9-\mathrm{wk}$ & 12 -wk & \multirow{2}{*}{ Mean $^{1}$} \\
\hline & 4,638 & 5,599 & 7,301 & $5,846^{\mathrm{a}}$ \\
17033 & 4,539 & 4,970 & 6,014 & $5,174^{\mathrm{b}}$ \\
17097 & 4,305 & 4,894 & 6,356 & $5,185^{\mathrm{b}}$ \\
Florigraze & 4,494 & 5,154 & 6,557 & RPP $\times \mathrm{HI}^{3}$ \\
Mean $^{2}$ & & & & \\
\hline
\end{tabular}

'Differences among means with different letters are statistically significant at $\mathrm{P}<$ 0.01 .

Linear increase with an increase in the harvest interval, $\mathrm{P}<0.01$.

Interaction between RPP line and $\mathrm{HI}$ was not significant at $\mathrm{P}<0.05$. 


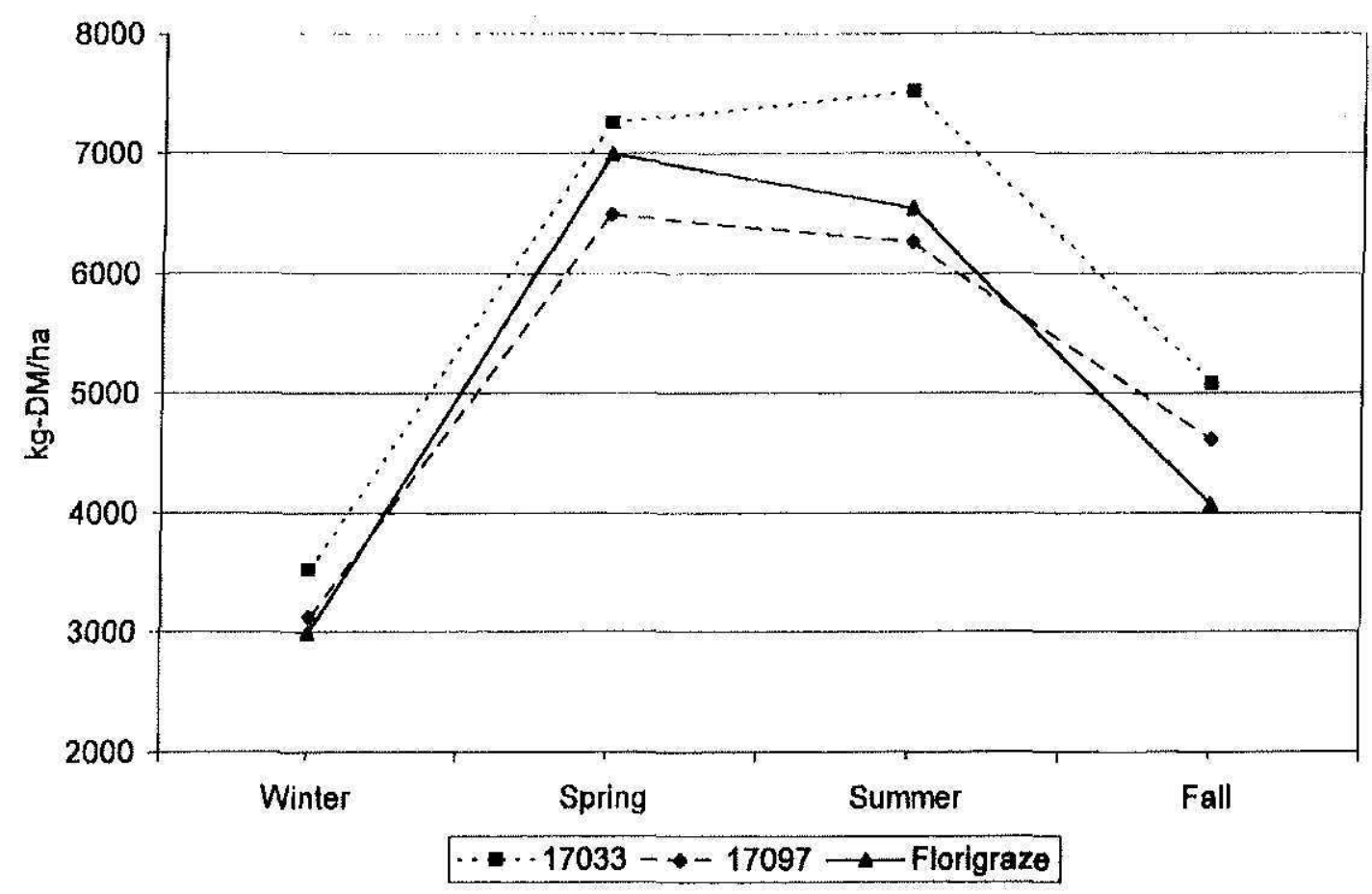

FIGURE 2. Dry matter yield of two accessions (USDA-TARS 17033 and 17097) and a cultivar (Florigraze) of rhizoma perennial peanut averaged for the six-, nine- and 12-wk harvests during the four seasons of the year in Juana Díaz.

clined dramatically $(\mathrm{P}<0.01)$, resulting in an average yield reduction of about $32.3 \%$ compared to that of summer yields. No interaction between season and variety was observed (Figure 2).

The effect of harvest interval on DMY was modified (interaction season $\times$ harvest interval, $\mathrm{P}<0.01$ ) by season of the year (Table 7). Yields of DM for the six- and nine-wk harvest intervals were similar except during the summer, when the nine-wk harvest produced $39.2 \%$ more $(\mathrm{P}$ $<0.01$ ). Conversely, DMY differences between the nine- and 12-wk harvests were significant $(P<0.01)$ for every season except summer. For the six- and nine-wk intervals, DMY was highest during summer; however, for the 12 -wk interval, yield was highest $(\mathrm{P}<0.01)$ during spring, $22.9 \%$ higher than during summer.

\section{Plant Height}

Mean height of plants for accession 17033 averaged for the three harvest intervals, was $44 \%$ greater $(\mathrm{P}<0.01)$ than for the average of the other two RPPS (Table 8). There was no difference in plant height between accession 17097 and cultivar Florigraze. Average plant height increased in a quadratic way $(\mathrm{P}<0.01)$ when harvest interval increased from six to 12 weeks. At six and nine weeks plant height was 
TABLE 7.-Dry matter (DM) yield per harvest of two accessions (USDA-TARS 17033 and 17097) and a cultivars (Florigraze) of rhizoma perennial peanut (RPP) harvested at six, nine- and 12-wk harvest intervals during the four seasons of the year in Juana Diaz.

\begin{tabular}{lccc}
\hline & \multicolumn{3}{c}{ Harvest interval (HI)1.2 } \\
\cline { 2 - 4 } Season & $6-\mathrm{wk}$ & $9-\mathrm{wk}$ & $12-\mathrm{wk}$ \\
\hline & $2,646^{\mathrm{b}}$ & $3,045^{\mathrm{b}}$ & $4,098^{\mathrm{n}}$ \\
Winter & $5,474^{\mathrm{b}}$ & $6,216^{\mathrm{b}}$ & $9,053^{\mathrm{b}}$ \\
Spring & $5,501^{\mathrm{b}}$ & $7,658^{\mathrm{b}}$ & $7,364^{\mathrm{a}}$ \\
Summer & $4,357^{\mathrm{b}}$ & $3,698^{\mathrm{b}}$ & $5,714^{\mathrm{a}}$ \\
Fall & & & \\
\hline
\end{tabular}

'Differences among means with different letters in the same row are statistically significant at $\mathrm{P}<0.05$.

${ }^{2}$ Interaction between season and $\mathrm{HI}$ was significant at $\mathrm{P}<0.01$.

similar. In contrast, there was a $5.5 \mathrm{~cm}$ increase from nine to 12 weeks of growth.

Season of harvest significantly $(\mathrm{P}<0.01)$ affected plant height. Peanut plants were tallest when harvested during summer (averaging 25.8 $\mathrm{cm}$ ). Average height declined during fall to $23.7 \mathrm{~cm}$, when averaged for harvest interval. A further average decline to $21.7 \mathrm{~cm}$ was recorded during the spring harvests. The shortest plants (averaging $11.5 \mathrm{~cm}$ ) were harvested during winter. Season modified $(\mathrm{P}<0.01)$ the effect of harvest interval on the height of peanut plants (Figure 3). Average

TABLE 8.-Plant height of two accessions (USDA-TARS 17033, and 17097) and a cultivar (Florigraze) of rhizoma perennial peanut harvested at six-, nine-, and 12-wh havest interval during a full year in Juana Diaz.

\begin{tabular}{|c|c|c|c|c|}
\hline \multirow[b]{2}{*}{ RPP } & \multicolumn{3}{|c|}{ Harvest interval (HI) } & \multirow[b]{2}{*}{ Mean ${ }^{1}$} \\
\hline & 6 -wk & $9-w k$ & $12-w k$ & \\
\hline & \multicolumn{4}{|c|}{$\ldots$} \\
\hline 17033 & 22.5 & 25.1 & 30.4 & $26.0^{a}$ \\
\hline 17097 & 15.8 & 16.4 & 20.6 & $17.6^{\mathrm{b}}$ \\
\hline Florigraze & 1.5 .5 & 16.4 & 23.7 & $18.5^{b}$ \\
\hline Mean $^{2}$ & 17.9 & 19.3 & 24.9 & $\mathrm{RPP} \times \mathrm{HI}^{3}$ \\
\hline
\end{tabular}




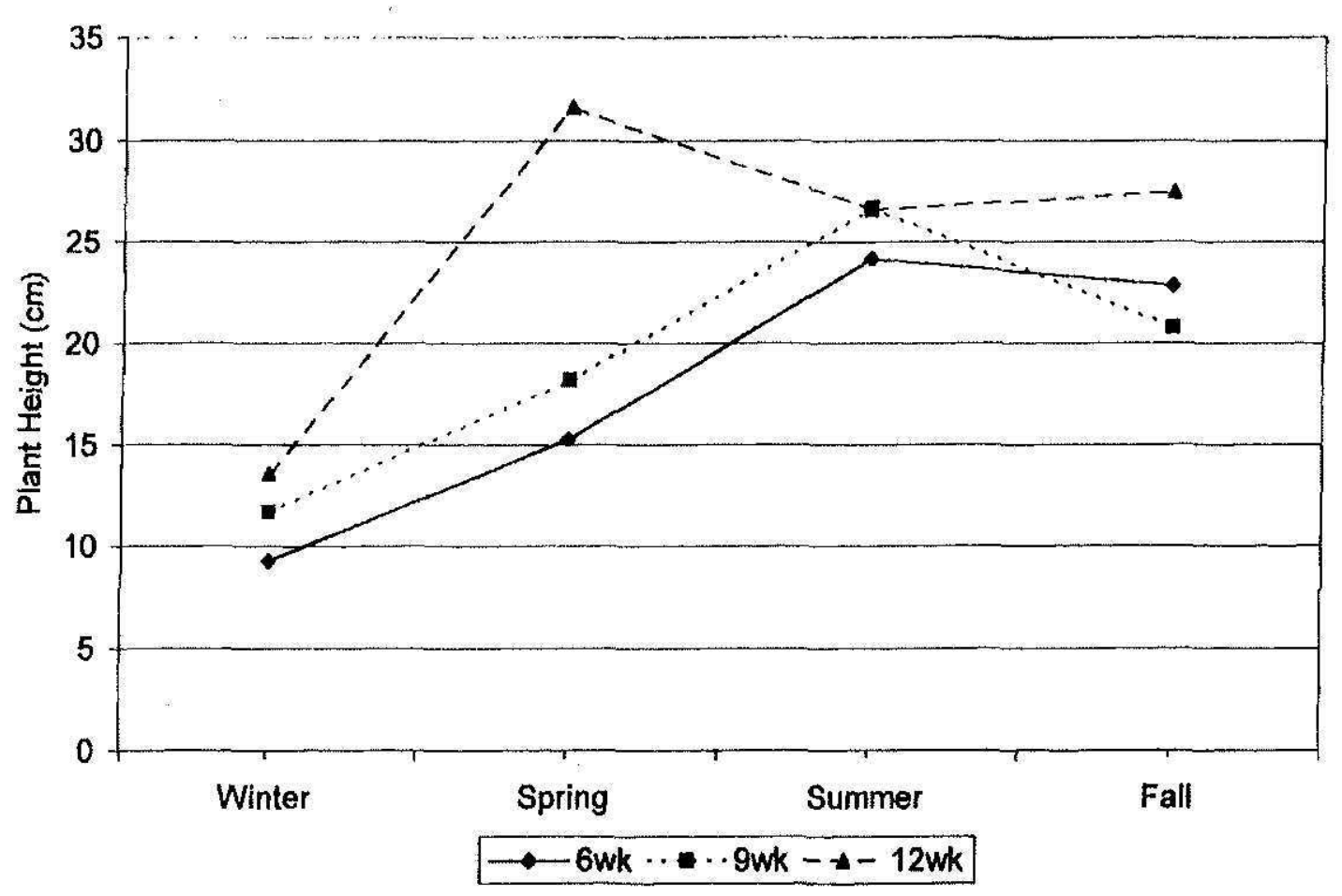

FIGURE 3. Plant height averaged for two accessions (USDA-TARS 17033 and 17097) and a cultivar (Florigraze) of thizoma perennial peanut at six-, nine- and 12-wk harvest intervals during the four seasons of the year in Juana Diaz.

height difference between the nine- and 12-wk harvest intervals was significant $(\mathrm{P}<0.01)$ during the spring and fall seasons but not different during the seasons when the shortest (winter) and tallest (summer) plants were harvested.

\section{DISCUSSION}

At both sites, yield of accession 17033 was highest; averaging for experiment and harvest interval $35,779 \mathrm{~kg} D \mathrm{DM} / \mathrm{h} / \mathrm{yr}$. Yield of accession 17097 , the second best producer in the Lajas experiment, was similar at both sites, averaging across harvest interval $30,697 \mathrm{~kg}$ DM/ha/yr. Cultivar Florigraze, which produced 14.4\% less than accession 17097 at Lajas, had similar productivity in Juana Díaz. Previously these three RPPs were grown in an Oxisol soil ( $\mathrm{pH}$ 6.5) without irrigation from June to November (Valencia et al., 1997). In that trial, cultivar Florigraze and accession 17033 produced 20.0 and $27.1 \%$ less, and 14.6 and $17.2 \%$ less (kg DM/ha) than accession 17097 at the six- and 12-wk harvests, respectively. Without irrigation, average yields of accessions 17033 and 17097 and cultivar Florigraze for the six- and 12-wk intervals were 2,410 and $4,242 \mathrm{~kg} \mathrm{DM} / \mathrm{ha}$, respectively. At Juana Díaz with irrigation, yields for 
the three RPPs at the six- and 12-wk intervals were 86.5 and $53 \%$ higher, respectively, than those reported without irrigation.

The yields of DM for the RPPs evaluated at the two sites were extremely high for a legume and are similar to the highest yields achievable by well-fertilized grasses in the tropics. Reported yields for pangola and star grasses harvested at 60 days of regrowth are in the range of 26,731 to $34,594 \mathrm{~kg} \mathrm{DM} / \mathrm{ha} / \mathrm{yr}$ when fertilized with at least 449 $\mathrm{kg} \mathrm{N}, 73 \mathrm{~kg} \mathrm{P}$, and $449 \mathrm{~kg} \mathrm{~K} / \mathrm{ha} / \mathrm{yr}$ (Vicente-Chandler et al., 1974).

Yield per harvest of the RPPs increased quadratically as harvest interval increased from six to 12 weeks in Lajas and linearly in Juana Díaz. The observed increases in average yield from six to 12 weeks were 25 and $46 \%$ at these sites, respectively. In comparison, increasing the harvest interval from 40 to 90 days between harvests for various tropical grasses resulted in yield increases per harvest ranging from about 98 to 318\% (Vicente-Chandler et al., 1974). As a consequence of the large increase in yield per harvest as harvest interval increased in tropical grasses, total yield (kg DM/ha/yr) increased significantly with an increase in harvest interval. For RPP we see the opposite relationship. This finding is due to the fact that most of the growth of the peanut plant occurs in the first six weeks. Growth per day of the three accessions in Juana Díaz (Table 6) was $107 \mathrm{~kg}$ DM/ha/d during the first six weeks, and only $47.5 \mathrm{~kg} \mathrm{DM} / \mathrm{ha} / \mathrm{d}$ from six to 12 weeks of regrowth.

Total average yield of accessions 17033 and 17097 and cultivar Florigraze decreased from 38,011 to $26,031 \mathrm{~kg} \mathrm{DM} / \mathrm{ha} / \mathrm{yr}$, a $46 \%$ decrease average for both locations as harvest interval increased from six to 12 weeks. In tropical grasses having similar harvest intervals of 40 and 90 days, increases in total yield ( $\mathrm{kg} \mathrm{DM} / \mathrm{ha} / \mathrm{yr}$ ) of $178 \%$ for napiergrass (Pennisetum purpureum), 55\% for guineagrass (Panicum maximum), 92\% for caribgrass (Eriochloa polystachya) and $52 \%$ for stargrass ( $C y$ nodon nlemfuensis) occurred as harvest interval increased (VicenteChandler et al., 1974).

For all RPPs, total yield was highest for the six-wk harvest interval. However, total yield ( $\mathrm{kg} \mathrm{DM} / \mathrm{ha} / \mathrm{yr}$ ) differences between the nine- and 12-wk harvests were significant $(P<0.01)$ in Lajas but not in Juana Díaz. Of the three RPPs studied in Juana Díaz, only 17097 showed a tendency for total yield ( $\mathrm{kg} \mathrm{DM} / \mathrm{ha} / \mathrm{yr})$ decline from the nine- to the 12wk harvest interval. The reverse was true when yield per harvest was considered. Again, the interaction between RPPs and harvest interval was not significant, and yield per harvest was lowest for the six-wk harvest interval at both locations. However, differences in yield per harvest between the nine- and 12-wk harvest intervals were significant in Juana Díaz and not in Lajas. In Lajas, average yields for the six-and nine-wk harvests of accessions 17033 and 17097 and cultivar Florigraze 
were 4,254 and 5,416 kg DM/ha, respectively. These were similar to the yields obtained for the six- and nine-wk harvests in Juana Díaz; however, average yield for the 12-wk harvest of these RPPs in Lajas $(5,500$ $\mathrm{kg} \mathrm{DM} / \mathrm{ha}$ ) was $16.1 \%$ lower than that in Juana Díaz (6,557 kg DM/ha). These discrepancies in yield between locations could be related to the fact that in Lajas, for reasons still unknown, there was considerable leaf loss for the 12-wk harvest. At both locations, there was no noticeable leaf loss from plants harvested at the six-and nine-wk intervals.

Season of harvest exerts a considerable influence on DMY of RPP. In Lajas and Juana Díaz, approximately 69 and 64\%, respectively, of total yield ( $\mathrm{kg} \mathrm{DM} / \mathrm{ha} / \mathrm{yr}$ ) was produced during the six months of spring and summer. Furthermore, on average, about $38 \%$ of the total yield was produced during summer at both sites. Dry matter yield dropped off dramatically during the driest and coolest seasons of the year (fall and winter). In each instance, yield across harvest interval for each RPP was lowest during winter. This behavior is a genetic adaptation, which enhances survivability of the plants in subtropical environments. This reduction in production during winter could also be accentuated by the fact that at both sites it is the driest and windiest season. Even when irrigation was used, the soil was visibly drier during winter than at any other season. Yields of cultivars Arbrook and Florigraze during fall and winter were among the lowest of the six RPPs studied in Lajas. By comparison, yields of accessions 17033 and 17097 were the highest and second best, respectively, during each of the four seasons studied. In Juana Díaz, the reduction in growth rate during fall and winter was more apparent for cultivar Florigraze than for either of the other two accessions (Figure 2). In contrast, yield of cultivar Florigraze was higher than that of accession 17097 during spring and summer. Perhaps this behavior may afford Florigraze better adaptability to the harsher fall and winter conditions of the southeastern United States, where it has been released as a commercial variety.

In Lajas, growth in winter was reduced to the point where differences in DMY per harvest among the nine- and 12-wk harvest intervals were not significant. Even though in Juana Díaz yield was depressed dramatically in winter, there was an increase in yield per harvest when harvest interval increased from nine to 12 weeks. Yield differences between the nine- and 12-wk harvests were significant in all seasons except summer (Juana Díaz). On the other hand, yield differences between the six- and nine-wk harvests occurred during summer, at both locations. Growth during summer appeared to be rapid and sustained up to about nine weeks.

Plants were taller in summer than fall and in fall than spring (Juana Díaz). The relationship of season and plant height does not 
agree with the pattern observed for DMY. During spring, DMY was greater than in fall. However, plants were taller in fall, with the exception of the 12-wk harvest in spring, which produced the tallest plants (Figure 3). Differences in height among harvest intervals were significant for all seasons except summer, when plants grew fastest, particularly for the six- and nine-wk harvest intervals.

Plants of accession 17033 were the tallest of all the RPPs studied (both locations) and produced the highest yields of DM. Across RPPS, there seems to be no direct relationship between height of the plant and DMY. Accession 17097 had one of the shortest plants and still was the second best producer. Plant height could be an important characteristic in determining main use of the RPP. It is reasonable to assume that the tallest plants should be better suited for hay production and mechanical harvesting and the shortest plants better suited for grazing. Some of the shortest plants, such as those of accession 17097, have a denser stand, thereby compensating for their lack of height and influencing yield in this manner. There seems to be a pattern of growth throughout the year within the same accession or cultivar. Plants are tallest during summer, when yield is the highest, and shortest during winter, when yield is lowest.

Results of this experiment clearly show the excellent production potential of RPP. Reported DMYs are comparable to those obtained from heavily fertilized tropical grasses under similar growing conditions. Such a high level of production is unprecedented for a legume forage under tropical conditions. In tropical grasses, an increase in harvest interval to increase DMY will be at the expense of nutritive value and quality of the grass. Total yield of RPP, unlike that of grasses, increases as harvest interval is shortened. This shorter interval would result in high DMYs with potentially better nutritive value and quality of the harvested forage. The great adaptability of RPP to the tropical environment and its high yield and low maintenance requirements when harvested for hay make RPP a crop with the potential of becoming one of the most important forages in the tropics.

\section{LITERATURE CITED}

French, E. C. and G. M. Prine, 1991. Perennial peanut: an alternative forage of growing importance. Univ. of Florida Cooperative Extension Service, Agronomy Facts SSAGR-39.

French, E. C. and G. M. Prine, 1989. Perennial peanut: an alternative forage of growing importance. Univ. of Florida Cooperative Extension Service, Agronomy Facts SSAGR-935.

Littell, R. C., R. J. Freund and P. C. Spector, 1991. SAS systems for linear models. Third Edition, SAS Institute Inc., Cary, NC, USA. 
Prine, G. M., L. S. Dunavin, J. E. Moore and D. Roush, 1981. "Florigraze" rhizome peanut, a perennial forage legume. Univ, of Fla. Agric. Exp. Stn. Circ. S-275.

Valencia, E., 1993. Agronomic and Morphological Evaluation of Perennial Peanut (Arachis spp.) in Western Puerto Rico. Master's Thesis, Univ. of Puerto Rico, Mayagüez.

Valencia, E., A. Sotomayor-Ríos and S. Torres-Cardona, 1997. Establishment and effect of cutting interval on yield and nutritive value of rhizoma perennial peanut in northwestern Puerto Rico. J. Agric. Univ. P.R. 81(1-2):19-30.

Venuto, B. C., D. D. Redfearn and W. D. Pitman, 1998. Rhizoma peanut responses to harvest frequency and nitrogen fertilization on Louisiana coastal plain soils. Agron. J. $90: 826$.

Vicente-Chandler, J., F. Abruña, R. Caro-Costas, J. Figarella, S. Silva and R. W. Pearson, 1974. Intensive grassland management in the humid tropics of Puerto Rico. Univ. of Puerto Rico Agric. Exp. Stn. Bulletin 233. 